\title{
LOS CONTRATOS ADMINISTRATIVOS Y EL DERECHO INTERNACIONAL DE LA INVERSIÓN: UNA BREVE APROXIMACIÓN
}

\author{
Dr. Javier Robalino Orellana ${ }^{1}$
}

\begin{abstract}
Extracto
Este trabajo aborda el concepto del contrato administrativo como una forma jurídica propia del derecho administrativo de origen europeo continental y su relación con el derecho internacional de la inversión, y analiza algunas instituciones de éste derecho supranacional que pueden ser aplicadas al contrato administrativo o a ciertas instituciones propias del derecho administratioo.
\end{abstract}

\section{INTRODUCCIÓN}

La situación actual de los contratos administrativos en muchos países de Latinoamérica se ha desarrollado de manera tal que los contratistas locales y extranjeros se han visto afectados en sus derechos contractuales, lo cual les ha requerido, ante la ineficiencia o ausencia de los mecanismos domésticos, acudir al derecho internacional. ${ }^{2}$

I. Profesor y Coordinador del Postgrado de Derecho Administrativo de la Universidad San Francisco de Quito, Ecuador. Miembro del Consejo Académico de la Cremades Calvo \& Sotelo, Madrid, España, Profesor visitante del Postgrado de Derecho de la Energía de la Universidad Carlos III de Madrid, Socio de Pérez Bustamante \& Ponce y Vicepresidente del Foro Iberoamericano de Derecho Administrativo. Fue asociado internacional para King \& Spalding, Houston, Texas. Doctor en Jurisprudencia, master en Derecho Intemacional en Duke University y abogado.

2. Véase Doak Bishop ef. al, Foreign Investment Dispufes, Ed. Kluwer Law, 2005, pp. 1-13. 
La aplicación del derecho internacional a los contratos administrativos se realiza a dos niveles. El primero de ellos se produce cuando el derecho internacional se ejerce en las relaciones jurídicas contractuales locales y ante los jueces o funcionarios administrativos del estado involucrado, por su introducción en el ordenamiento jurídico doméstico. ${ }^{3}$ El segundo nivel se presenta cuando el derecho internacional se aplica internacionalmente, ante tribunales internacionales, en la capacidad misma del Estado como sujeto del derecho internacional público, mas no como la mera Administración Pública interna. Estos dos niveles pueden verse combinados eventualmente cuando las relaciones contractuales y la solución de disputas envuelven actuaciones domésticas e internacionales, cuando se discute la supremacía de las normas domésticas vis-à-vis las normas internacionales o cuando existe una controversia sobre la jurisdicción de una cierta controversia de origen contractual.

Sin embargo, la aplicación del derecho internacional, en cualquiera de los niveles antes indicados, produce conflictos y problemas en los países que se ven sujetos al derecho internacional y que se han sometido al mismo. Este tema tiene particular relevancia cuando los contratos administrativos involucran proyectos de importancia nacional, situación que se ve agravada cuando los gobiernos afrontan crisis que afectan la estabilidad y equilibrio de dichos contratos, o cuando los mismos, por razones internas, son terminados y los activos e inversiones, revertidos a favor del Estado. A continuación trataremos de hacer una aproximación a esta problemática. Para el efecto, comenzaremos por analizar la naturaleza del contrato administrativo, para luego movernos hacia los principios del derecho internacional que, en determinadas circunstancias, tienen ingerencia en los contratos administrativos.

3. Agustín Gordillo, Tratado de Derecho Administrativo, 8va ed., Ed. Fundación de Derecho Admintistrativo, Bs. As, 2003, p. V-2 a V-22. El autor le da al derechó intemacional el carácter de fuente del derecho administrativo y del derecho doméstico, bajo el concepto de supranacionalidad. Gordillo afirma con acjerto que el "derecho internacional público habia sentado la superioridad de stus normas (ius cogens) sabre el derecho interno, ahora empleza a admitirlo el derecho interno ante la presión internacional, Más aún, nuestros tratados bilaterales de promoción de inversiones extranjeras autorizan al inversor a someter sus diferendos a un tribunal arbitral internacional". 


\section{ELEMENTOS RELEVANTES DEL CONTRATO ADMINISTRATIVO}

Cabe indicar que el contrato administrativo es una producción jurídica de los estados en los que el derecho administrativo se ha desarrollado como una rama independiente del derecho, como son Alemania, Francia, Italia, Argentina, México o España y de los países que han seguido su ejemplo, mas no se encuentra esta forma contractual en los países del sistema anglosajón. Por lo tanto, este análisis se limita a aquellos países que siguen la vertiente jurídica franco-continental, y en los que además, el derecho administrativo se ha desarrollado de manera en que se distingue el contrato común del contrato administrativo.

El contrato administrativo es una manifestación bilateral de voluntad, en la que al menos una de las partes se encuentra revestida de o ejerce una potestad administrativa, y que es por lo tanto, productora de efectos jurídicos. ${ }^{4}$ Esta definición requiere ser desglosada con el ánimo de comprender cada uno de sus elementos.

Una parte del contrato administrativo, el Estado o su personificación interna la Administración Pública, comporta relevancia esencial para efectos de este debate, pues vincula al Estado a dicha relación. Esta vinculación del Estado constituye el antecedente esencial que permite la aplicación del derecho internacional de la inversión al contrato administrativo debido a la presencia del Estado, el que a su vez, se convierte en sujeto de una relación internacional, como veremos en detalle más adelante.

Id. p. VI-4. Posteriormente el mismo autor afirma sobre el derecho internacional que "estas normas $y$ principios juridicos constitzyen no solamente derecho supranacional sino tambièn al propio tiempo, derecho interno, vigente, operativo, aplicable de pleno derecho a toda situación que quepa encuadrar en ellos... La Convención y otras normas supranacionales tienen asi el doble carácter señalado, que implica la obligación de las autoridades nacionales de cumplirlas y ejecutarlas, sin perjutcio de la aplicación que también harán de ellas las autoridades judiciales supranacionales existentes segin el caso" Id. p. VI-18 VI-19.

4. Roberto Dromi, Derecho Administrativo, Ed. Ciudad Argentina, 2002, pp. 474-477. 
El otro elemento del contrato administrativo es la presencia del Estado, ejerciendo una potestad administrativa, lo cual lo califica como tal, es decir, como un contrato administrativo, y lo distingue de otros contratos (v.g. contratos civiles, comerciales, laborales, etc., en los que también participa el Estado, pero sin ejercer potestades administrativas) que puede suscribir la Administración, y por lo tanto, lo somete al derecho administrativo. Sometido al derecho administrativo, el contrato administrativo se rige por el marco legal propio de esta rama del derecho. La pregunta es si es posible que el derecho administrativo se vea desplazado por otra rama del derecho en lo que se refiere al contrato administrativo propiamente dicho.

El contrato administrativo, como muchas manifestaciones la voluntad, y siendo como es una relación sinalagmática, aunque revestida de ciertas particularidades e incluso cláusulas exhorbitantes, es evidentemente productora de efectos jurídicos, es decir, derechos y obligaciones para el Estado y el contratista. Dichos efectos provienen del principio de responsabilidad estatal y no se limitan al derecho administrativo, y se pueden extender a otras esferas, como el derecho internacional, a las que el propio Estado se ha sometido legítimamente.

Los contratos administrativos son de varios tipos y comprenden distintas actividades. Estos podrán referirse a la delegación o concesión de actividades reservadas al Estado como la prestación de servicios públicos de telecomunicaciones, energía, transporte, y otros. Los contratos administrativos también pueden referirse a actividades como la exploración y explotación de recursos naturales, minerales o forestales, o a la prestación de servicios o venta de bienes. En sus diversas formas, el contrato administrativo se forma, suscribe, ejecuta y liquida bajo normas públicas administrativas, las que generalmente son muy desarrolladas y vienen acompanadas de reglamentos y regulaciones. En este punto, encontraremos una seria diferencia con el derecho internacional, el que no sólo es menos desarrollado en normas secundarias, sino que además regula y protege valores 
más generales antes que específicos como aquellos regulados por el derecho administrativo.

Adicionalmente, el contrato administrativo es peculiar en cuanto es un medio para el desarrollo de una actividad pública y en algunos casos, reservada al Estado, el que decide delegarla a un sujeto particular. Sin embargo, la naturaleza de esa actividad lleva implícita la presencia de valores superiores como el bien común, el progreso, el desarrollo y la solidaridad del servicio público. Estos valores constituyen el sustento para que el Estado pueda tener una posición predominante sobre el contratista.

Más aún, el contrato administrativo se satisface con recursos públicos o puede permitir el uso de recursos públicos, los que $a b$ initio están sujetos al derecho administrativo y a las normas y principios de la hacienda pública, lo cual, particulariza al contrato administrativo desde el procedimiento precontractual en el que se configura su voluntad, pasando por su ejecución y concluyendo en la liquidación del mismo. Por lo tanto, si bien el contrato administrativo puede tener algunas semejanzas con respecto del contrato civil o comercial, su formación, desarrollo y terminación tienen sustanciales diferencias con las de aquel.

\section{LOS CONTRATOS ADMINISTRATIVOS Y LA RESOLUCIÓN DE SUS CONTROVERSIAS}

Como se ha indicado antes, los contratos administrativos se encuentran generalmente sometidos a las normas del derecho administrativo, y por lo tanto, las controversias derivadas de ellos en los países de tradición continental, son sometidas comúnmente a una jurisdicción especializada para estos contratos, generalmente asignada a los tribunales de lo contencioso administrativo ${ }^{5}$. Dichos tribunales conocen las disputas relacio-

5. En la mayoría de paises latinoamericanos y europeos se ha establecido la jurisdicción contencioso administrativo o se ha seguido el modelo del Consejo de Estado francés, como órgano revisor de las actuaciones del Estado. 
nadas a tales contratos, así como otras controversias relativas a manifestaciones de la voluntad administrativa (e.g. actos administrativos, reglamentos o hechos administrativos). Estos tribunales especializados conocen de los contratos administrativos y resuelven las disputas relativas a los mismos, permitiendo generalmente una revisión de sus sentencias en la propia sede o ante un tribunal superior. ${ }^{6}$

Otra jurisdicción aplicable a los contratos administrativos es aquella de naturaleza convencional, es decir, el arbitraje. Muchos países han incorporado en sus ordenamientos jurídicos leyes domésticas que permiten la resolución de controversias entre el Estado y un contratista, y más aún, que permiten la resolución de controversias provenientes y originadas en contratos administrativos. Por lo tanto, las controversias derivadas de contratos administrativos pueden también someterse al arbitraje local.

Una tercera jurisdicción aplicable a los contratos administrativos es la del arbitraje internacional, el cual también puede pactarse entre el Estado y un contratista privado. De manera particular, la Convención de Washington ${ }^{7}$ estableció el Centro Internacional para la Solución de Controversias Relativas a Inversiones (CIADI), y es común que las partes de un contrato establezcan una cláusula arbitral que someta las controversias de un contrato administrativo al CIADI ${ }^{8}$. Otros foros o procedimientos de arbitraje internacional que suelen pactarse en contra-

6. Sin embargo, existen casos como el de Chile, que no han adoptado aún los tribunales de lo contencioso administrativo o similares. Sin embargo, incluso en esos casos, cxisten procedimientos especiales ante jueces ordinarios para resolver las controversias derivadas de dichos contratos. Ese también era el caso de Ecuador antes de la expedición de la Ley de Modernización del Estado de 1993 que remitió los contratos administrativos a los tribunales de lo contencioso administrativo.

7. También denominada Convenio sobre Arreglo de Diferencias Relativas a Inversiones que tiene 143 paises suscriptores que la han ratificado a la fecha. Véase http://www.worldbank.org/icsid/.

8. La Convención de Washington establece que para que se aplique el arbitraje del CIADI, el Estado y el Estado del inversionista deben ser partes de la Convención. Sin embargo, el CIADI también tiene un arbitraje, bajo las normas de la Facilidad Adicional, en el que solo se requiere que una de las partes sea contratante de la Convención. Muchos de los casos NAFTA han sido sometidos bajo la Facilidad Adicional, ya que ni Canadá ni México son parte de la Convención de Washington, Véase http://www, worldbank.org/icsid/. 
tos administrativos cuando la legislación doméstica lo permite son la Cámara de Comercio Internacional de París (CCI) o UNCITRAL. ${ }^{9}$ En estos casos, generalmente la ley aplicable y sobre la que deberán emitir su opinión los árbitros es la ley del Estado, es decir, el derecho doméstico, aunque el foro o procedimiento sea internacional. En otras palabras, la ley sustantiva de estos arbitrajes es el derecho doméstico del Estado contratante, pero dentro de un procedimiento internacional.

\section{PRINCIPALES CONCEPTOS DEL DERECHO INTERNACIONAL APLICABLES A LOS CONTRATOS ADMINISTRATIVOS}

Las esferas del derecho administrativo e internacional son diferentes. Sus fuentes, áreas y límites difieren. Sin embargo, trataremos de considerar a cada una de esas ramas como un conjunto de normas, a las que mediante un diagrama de Venn imaginario, intentaremos superponer parcialmente, determinando los casos de tal superposición.

El derecho internacional público ha sido generalmente concebido como una rama del derecho, en la que las partes de cualquier disputa eran exclusivamente los estados soberanos. En el siglo $X X$ se establece la primera corte internacional dedicada a la resolución de controversias entre estados que fue la Corte Permanente de Justicia Internacional, que luego de la Segunda Guerra Mundial es reemplazada por la Corte Internacional de Justicia (CIJ). El Estatuto de la CIJ establece claramente que su competencia se limita a las controversias entre estados y no se extiende, de manera alguna, a los sujetos particulares. Otras cortes similares a la CIJ se han establecido como es el caso de la Organización Mundial de Comercio, cuyo mecanismo de solución de controversias es privativo para los estados soberanos.

9. Se refiere a la "United nations commission of International Trade Law"l (UNCITRAL), que establece solo un procedimiento $a d-h o c$ de arbitraje y no establece un centro arbitral como son CIADI 0 CCI. 
Sin embargo, el derecho internacional público ha dado un paso importante al permitir que sujetos particulares -no soberanos-, puedan acceder a la justicia internacional, ampliando el ámbito del derecho internacional de uno solo para los estados, a un derecho más dinámico en el que los particulares pueden exigir determinados derechos de manera directa a los estados. A continuación algunos ejemplos. La Corte Interamericana de Derechos Humanos es competente para conocer reclamos de particulares sobre violaciones a los derechos humanos. ${ }^{10}$ Asimismo, el Tribunal Andino de Justicia con sede en Quito, Ecuador, y creado por la Comunidad Andina de Naciones, también puede conocer ciertas demandas de particulares en contra de los estados miembros, como expresamente lo dispone su estatuto de creacion. ${ }^{11}$ Igualmente, la Corte Europea de Derechos Humanos es también competente para conocer los reclamos de particulares por violaciones de derechos humanos.

La evolución del derecho internacional, originalmente motivada por la protección de derechos humanos y de ciertas garantías básicas, es el precursor jurídico que da paso a lo que se podría denominar actualmente el derecho internacional de la inversión que está dentro del derecho internacional público, en el cual, los particulares inversionistas están protegidos y pueden reclamar directamente a un estado receptor de la inversión. Esta rama del derecho internacional público se origina en los denominados acuerdos de comercio, amistad y navegación. ${ }^{12}$ Sin embar-

10. Creada por mandato de la Convención Interamericana de Derechos Humanos.

11. Tribunal de Justicia de la Comunidad Andina ("TJCA") es un ente creado por el converio de creación de la Comunidad, luego reglamentado por la correspondiente Decisión del Acuerdo de Cartagena No. 472, y que contiene el TRATADO DE CREACION DEL TRIBUNAL DE JUSTICIA DE LA COMUNIDAD ANDINA. El Art. 17 dispone:

"Art. 17.- Corresponde al Tribunat declarar la nulidad de las Decisiones del Consejo Andino de Ministros de Relaciones Exteriores, de la Comisión de la Comunidad Andina, de las Resoluciones de la Secretaria General y de los Convenios a que se refiere el literal e) del articulo 1 , dictados o acordados con violación de las normas que conforman el ordenamiento jurídico de la Comunidad Andina, incluso por desviación de poder, cuando sean impugnados por algún País Miembro, el Consejo Andino de Ministros de Relaciones Exteriores, la Comisión de la Comunidad Andina, la Secretaria General o las personas naturales o juridicas en las condiciones previstas en el artículo 19 de este Tratado".

12. En inglés denominados "friendship, commerce and navigation treaties or FCN". 
go, en la segunda mitad del siglo $\mathrm{XX}$, dichos tratados evolucionan en una nueva modalidad conocidos como convenios o tratados bilaterales de inversión. ${ }^{13}$ Estos últimos se producen como una respuesta política de los países desarrollados, orientada a proteger a los inversionistas en casos de nacionalización o expropiación de inversiones, particularmente, Iuego de la denominada época de las nacionalizaciones, ${ }^{14}$ y se caracterizan, no sólo por permitir la acción directa de un inversionista en contra de un Estado, sino que, además, contienen varios principios propios del derecho internacional que tienen efectos en los contratos administrativos.

Actualmente, el derecho internacional público de la inversión continúa desarrollándose. Por ejemplo, los Estados Unidos de América han negociado varios tratados de libre comercio que incluyen capítulos dedicados a la inversión extranjera, o en otras palabras, incluyen un tratado de inversión dentro de un tratado de comercio. Adicionalmente, las recientes medidas adoptadas por Argentina, Venezuela, Bolivia, y Ecuador han producido una explosión de demandas de inversionistas en contra de estados latinoamericanos, muchas de ellas relativas a contratos administrativos. ${ }^{15}$

Para el efecto mencionaremos los principales principios o estándares del derecho internacional público de la inversión que

13. En inglés denominados "bilateral investment treaties or BIT's". El primcto de estos es cl suscrito entre Alemania y Pakistán en 1956. A la fecha existen más de 2200 tratados bilaterales de inversión suscritos y vigentes.

14. Las nacionalizaciones petroleras durante los años 1930's y 1970's en Latinoamérica, las cxpropiaciones en Irán y otros eventos aceleraron el desarrollo de los tratados bilaterales de inversión.

15. Véase www.icsid.com. Adicionalmente, en el caso de Bolivia, el reciente decreto del señor Presidente Evo Morales denominado "Defensores del Chaco" que dispuso la nacionalización de los activos petroleros privados dará lugar a acciones internacionales en contra de Bolivia por parte de inversionistas como la brasileña Petrobrás. Tal decreto dispuso la inmediata transferencia de todos los activos a la empresa cstatal Yacimientos Petrolíferos Fiscales Bolivianos (YPFB). Otro cjemplo reciente cs el caso de la terminación unilatcral (caducidad) del contrato de exploración y cxplotación de hidrocarburos que la cmpresa Occidental Exploration and Production Company (OXY) por parte del Ecuador, y la inmediata interposición de una petición arbitral ante el ICSID. Por su parte, Argentina, lucgo de la crisis del año 2000-2001, ha recibido más demandas intemacionales que cualquier otro país en la historia. Muchas de cllas resueitas y otras no, sin duda han traido el tema del derecho internacional de la inversión a uná esfera local, en la que los paises se cnvuelven en debates sustanciales sobre la vigencia de los tratados y los derechos afcctados. 
tienen aplicación a los contratos administrativos, o que elevan las disputas de un contrato administrativo al plano del derecho internacional. Ellos comprenden la no discriminación, la no expropiación y el trato justo y equitativo.

En términos generales, la no discriminación debe ser entendida como un tratamiento igual o no menos favorable que otorga el Estado receptor de la inversión al inversionista en comparación con el tratamiento que el mismo estado otorga a inversionistas nacionales y extranjeros. La no discriminación comprende dos sub-estándares, que son el trato nacional y la clásula de la nación más favorecida ${ }^{16}$. En otras palabras, dicho tratamiento deber ser igual o no menos favorable que aquel que el Estado otorga a sus propios nacionales (trato nacional), y también debe ser igual o no menos favorable que el tratamiento que el Estado receptor otorga a los nacionales de otros países (cláusula de la nación más favorecida). ${ }^{17}$ La no discriminación es uno de los denominados estándares relativos del derecho internacional de la inversión, pues su medida se realiza en función de una comparación que debe realizar el inversionista afectado de su situación particular con la de otros inversionistas nacionales o extranjeros

16. El Tratado de Protección Reciproca de Inversiones entre Ecuador y Estados Unidos de América dispone:

"Art. 2.- 1. Cada Parte permitiná y tratará las inversiones y stis actividades afines de manera no menos favorable que la que otorga en situaciones similares a las inversiones o actividades afines de sus propios nacionales o sociedades, o las de los nacionales o sociedades de cualquier tercer pais, cualquiera que sea la más favorable, sin perjucio del derecho de cada Parte a hacer o mantener excepciones que correspondan a alguno de los sectores o asuntos que figuran en el Anexo del presente Tratado...."

Véase también el Acuerdo GATT 1964 y los tratados de la Organización Mundial de Comercio. El trato nacional y la cláusula de la nación más favorecida provienen inicialmente del derecho internacional del comercio.

17. Id. El mismo artículo 2 dispone:

“... a) Lo dispuesto en el presente Tratado no impedirá que las Partes mantengan o establezcan empresas estatales.

b) Cada Parte se asegurará de que las empresas estatales que mantenga o establezca actúen de manera compatible con las obligaciones de esa Parte en virtud del presente Tratado, ctando ejerzan cualquier facultad reguladora, administrativa o puiblica que le haya sido delegada por esa Parte como, por ejemplo, la facultad de expropiar, otorgar licencias, aprobar operaciones comerciales o imponer cuotas, derechos u otros gravámenes.

c) Cada Parte se asegurart de que las empresas estatales que mantenga o establezca concedan el mejor trato, ya sea el nacional o el de la nación más favorecida, a la venta de stis bienes o senicios en el territorio de la Parte." 
en similares circunstancias. Por lo tanto, habrá discriminación en la medida en que el Estado receptor otorgue al inversionista un tratamiento desigual o menos favorable en comparación con aquel otorgado a otros inversionistas nacionales o extranjeros.

La no expropiación protege la inversión de un nacional de un Estado respecto de las actuaciones del Estado receptor de la inversión que representen una exacción de la propiedad del inversionista. $\mathrm{Al}$ respecto, corresponde anotar que la expropiación, inicialmente desarrollada en el derecho internacional consuetudinario y luego considerada por la Corte Permanente Internacional de Justicia ${ }^{18}$. Recientemente, el concepto de expropiación ha sido desarrollado y ampliado, con el objetivo de establecer mayores limitaciones a la actuación de los soberanos, de manera que los actuales convenios de protección de inversión contemplan que la expropiación debe satisfacer ciertos requisitos básicos para ser posible ${ }^{19}$, sin perjuicio de los requisitos de la ley local, aunque no totalmente desvinculada de dicha ley.

Por ejemplo, los más recientes convenios de protección de inversiones ${ }^{20}$ requieren que la expropiación cumpla con los siguientes requisitos ${ }^{21}$ :

18. Véase ế caso de la Fábrica en Chorzów, en el cual, dicha corte determinó la existencia de una expropjación derechos intangibles o "good will". Caso No. 13 de la Corte Permanente Internacional de Justicia.

19. Véașe el Modelo de Convenio de Protección Reciproca de Inverșiones de los Estados Unidos de América, www.ustr.gov, Véase tambiến el capitulo de inversiones del Acuerdo de Libre Comercio entre Chile y Estados Unidos de América. http://www.ustr.gov/assets/Trade_Agreements/Bilateral/Chile_FTA/Final_Texts/asset_upload_filel_ 4004.pdf?ht=.

20. Id.

21. Id. Por ejemplo, el Tratado de Protección Reciproca de Inversiones suscrito entre Ecuador y los Estados Unidos de América đispone:

Art. 3.- 1. Las inversiones no se expropiarán ni nacionalizarán directamente, ni indirectamente mediante la aplicación de medidas equivalentes a la expropiación o nacionalización ("expropiación"), salvo que ello se efectie confines de interés ptiblico, de manera equitativa y ntedlante pago de una indemnización pronla, adecuada y efectiva, y de conformidad con el debido procedimiento legal y los principios generales de trato dispuestos en el párrafo 3 del articulo 2. La indem. nización equivaldrá al valor justo en el mercado que tenga la inversión expropiada inmediatamente antes de que se tome la acción expropiatoria o de que ésta se llegue a conocer, si ello ocurre con anterioridad: se calculará en una moneda utilizable libremente, al tipo de cambio vigente en el mercado en ese momento, se pagará sin dilación; inchirá los iniereses devengados a un tipo de interés comercialmente razonable desde la fecha de la expropiación; será enteramente realizable, y será transferible libremente...". 
(i) Se realice por razones y fines de orden público. Debe existir una necesidad pública y un fin social que satisfacer.

(ii) El inversionista reciba pronta, adecuada y efectiva compensación. Es decir, el pago del valor económico que restituya la inversión debe realizarse sin demora, por el monto justo y en moneda libremente convertible.

(iii) La compensación debe ser equivalente al valor de mercado de la inversión. Los recientes tratados de inversión han buscado codificar la costumbre internacional proveyendo criterios más claros para la valoración de la inversión, generalmente ligando la inversión a los valores de mercado, para efectos de su valoración.

Adicionalmente, el derecho internacional hace referencia a que la expropiación no puede ser ni directa ni indirecta, es decir, no puede ser de aquellas que prima facie constituyan una expropiación ni tampoco de aquellas que de manera oculta o simulada configuran una expropiación. ${ }^{22}$ La doctrina ha divido las formas de expropiación en de jure o de facto, entendiendo a la primera (de jure) como aquella que se realiza de conformidad con la ley doméstica, y a la segunda (de facto) como la expropiación que se realiza fuera de la ley doméstica, y que por lo tanto, puede ser simplemente un hecho ilegal expropiatorio, o puede ser oculta o indirecta, pero con efectos expropiatorios. En ambos casos debe existir una compensacion.

El tercer estándar, calificado en la doctrina como uno de aquellos absolutos, es el denominado trato justo y equitativo ${ }^{23}$. El trato justo y equitativo comprende el tratamiento equilibrado y transparente por parte del Estado, de manera que no afecte los derechos de los inversionistas.

22. $l d$.

23. Id. El Artículo 2 dispone también:

“3. a) Las inversiones, a las que se concederá siempre un trato justo y equitativo, gozarán de protección y segtaridad plenas y, en ningin caso, se les concederán tul trato menos favorable que ol que exige el derecho internacional." 
Estos estándares o principios del derecho internacional público de la inversión se han incorporado en los ordenamientos jurídicos de muchos estados soberanos y se aplican frecuentemente. Más aún, muchas leyes domésticas, denominadas leyes de inversión, han importado a las legislaciones locales los estándares antes indicados, fomentando una interacción aún mayor entre el derecho internacional y el derecho administrativo que ha recogido en muchos países estos principios del derecho internacional de la inversión, sea por mandato de los propios tratados internacionales, o por desarrollo de la legislación orientada a promover nuevas inversiones. ${ }^{24}$

\section{NEXO ENTRE EL DERECHO INTERNACIONAL $Y$ EL CONTRATO ADMINISTRATIVO}

El nexo o vínculo entre el derecho internacional de la inversión y el derecho administrativo (y por lo tanto, en algunos casos, con el contrato administrativo) proviene de dos elementos importantes que son: (i) los conceptos de inversión e inversionista en el derecho internacional; $y$, (ii) la presencia del Estado como parte contractual que ejercita una o varias potestades.

Los convenios de protección de inversiones se aplican solo cuando existe una inversión y un inversionista titular de esa inversión. La inversión (ratione materia) se define en los convenios generalmente de una manera amplia que incluye cualquier bien tangible o intangible del inversionista, lo cual incluye derechos contractuales, concesiones, permisos o licencias, y también, los bienes materiales o activos de los inversionistas involucrados en el contrato administrativo. ${ }^{25}$ Por lo tanto, el contrato admi-

24. Por cjemplo, paises como Argentina, México o Ecuador han adoptado legislaciones que protegen la inversión y contemplan estándares de inversión compatibles con el derecho internacional.

25. Id. supra nota 16. El Articulo I dispone:

"Art. $I$."

1. A efectos del presente tratado:

a) inversión" significa todo tipo de inversión tales como el capital social, las deudas y los contratos de servicio y de inversion, que se haga en el territorio de una Parte y que directa o indirectamente sea propiedad de nacionales o sociedades de la otra Parte o esté controlada por dichos nacionales o sociedades, y comprende: 
nistrativo es visto por el derecho internacional como una inversion, y siendo tal, el derecho administrativo podría verse supeditado o superado por el derecho internacional al momento de analizar una inversión-contrato bajo la "lupa" internacional.

Sin embargo, debe mencionarse que la "lupa" internacional puede utilizarse sea en la esfera doméstica como en la internacional, pues los países suscriptores de los convenios internacionales están también obligados a aplicar los convenios y tratados, así como sus órganos e instituciones ${ }^{26}$, una vez que han ratificado el tratado y lo han incorporado a su ordenamiento jurídico. ${ }^{27}$

Junto con el concepto inversión, existe el concepto inversionista (ratione personae) también necesario para activar la aplicación del derecho internacional de la inversión. Si bien los tratados de inversión se suscriben entre soberanos, tales soberanos han permitido que sus nacionales o ciudadanos particulares y titulares de una inversión (inversionistas), puedan acceder a los beneficios del derecho internacional. Sin embargo, para ello deben calificarse como inversionistas, quienes comúnmente se entienden como las personas naturales o jurídicas propietarias

i) Los bienes corporales e incorporales, incliso derechos tales como los de retención, las hipotecas y las prendas;

ii) Las sociedades o las acciones de capial u otras participaciones en sociedades o en sus activos:

iii) El derecho al dinero o alguna operación que tenga valor económico y que esté relacionada con una inversión;

iv) La propiedad intelectual que, entre otros, comprende los derechos relativos a:

las obras attisticas y literarias, incluidas las grabaciones sonoras;

los inventos en todos los ámbilos del esfuerzo humano:

los diseños industriales;

las obras de estampado de semiconductores;

los secretos comerciales. los conocimientos técnicos y la información comercial confidencial. $y$ las marcas registradas, las marcas de servicio y las nombres comerciales; $y$,

v) Todo derecho conferido por ley o por contrato y cualesquiera licencias y permisos conferidos conforme a la Ley."

26. Vease Convención de Viena sobre el Derecho de los Tratados.

27. En el derecho internacional se distinguen los paises que consideran a los tratados de ejecución directa y los paises que requieren una ley de implementación del tratado. Entre los paises que comúnmente requieren ura ley de implementación de los tratados se encuentra los Estados Unidos de América que califica a algunos tratados como "non self-executing". Curtis Bradley, etal, Public international Law. 
de una inversión, y que son además nacionales o de propiedad de nacionales del otro estado parte del tratado. ${ }^{28}$

Una vez que existe una inversión y un inversionista, entonces puede haber lugar a la aplicación del derecho internacional de la inversión. ${ }^{29}$ Sin embargo, como se ha indicado, el derecho internacional de la inversión se aplicará por parte de un inversionista en contra del Estado que ha sido anfitrión de la inversión o por parte del Estado en las relaciones con sus inversionistas, y sobre la base, de los principios y derechos sustantivos del derecho internacional antes mencionados. Tal aplicación envuelve necesariamente la presencia del Estado o de sujetos $u$ órganos que actúan por cuenta del Estado. Por ejemplo, no cabe la aplicación del derecho internacional público de la inversión a una relación comercial entre el inversionista y un comerciante en el país receptor de la inversión. Se requerirá por el contrario que exista la presencia del Estado, a través de uno de los órganos que lo conforman o personifican como Administración Pública o de un delegatario del Estado ${ }^{30}$, para que eventualmente se pueda aplicar el derecho internacional de la inversión a un contrato administrativo. Por lo tanto, la presencia del Estado (o la Administración Pública) son requisitos indispensables para la aplicación del derecho internacional de la inversión, junto, con

28. Véase supra nota 22. La definición de inversión hace referencia a la propiedad de una nacional del otro estado parte del tratado. El Articulo I del mismo tratado define:

"b) "Sociedad" de una Parte significa cualgutier clase de sociedad anónima, compañia, asociación, sociedad comanditaria u otra entidad legalmente constituida conforme al ordenamiento interno de tha Parte o de usia subdivisión política de la misma, tenga o no fines de hicro y sea de propiedad privada o pública;

c) "Nacional" de tha Parte significa la persona natural que sea nacional de tha Parte de conformidad con su legislacion."

29. Generalmente los requisitos de inversión (ratione materia) e inversionista (ratione personae) se agrega un tercer requisito, que es el de ticmpo (ratizone temporis) que usualmente determina si cl reclamo en el ámbito del derecho internacional debe realizarse dentro de una determínada ventana de tiempo.

30. Id supra nota 16. E] Artículo I define:

"f) "Enpresa estatal" significa la empresa que sea propiedad de una de las Partes o que esté controlada por esa Parte mediante derecho de propiedad.

g) "Delegación" significa la concesión legislativa y la orden, norma u otra disposición oficial que transfieran autoridad gubernamental a una empresa o monopolio estatal, o le autoricen el ejercicio de dicha autoridad."

Además, el Articulo 11 dispone que el "presente Tratado se aplicará a las subdivisiones políticas de las Parte". 
los requisitos antes indicados, no exclusivamente como contrapartes del contrato administrativo, sino como reguladores de una determinada actividad, o simplemente como emisores de actos legislativos, administrativos o normativos de cualesquiera órgano del superorganismo Administración Pública, e incluso por omisiones de dicha Administración.

Ergo, vemos que el nexo o vínculo entre el derecho internacional de la inversión y el contrato administrativo se producirá cuando exista un tratado bilateral de inversión, que por un lado proteja una inversión (en o a través de un contrato administrativo), y un inversionista de un Estado, y por otro lado, un Estado receptor de la inversión que debe aplicar tal tratado o en su defecto, remediar ${ }^{31}$ el daño a la inversión del otro Estado en los términos del mismo tratado.

\section{FORMAS ADMINISTRATIVAS CON INCIDENCIA EN EL DERECHO INTERNACIONAL DE LA INVERSIÓN}

Con el afán de determinar de una manera visible la relación entre el derecho administrativo, los contratos administrativos y el derecho internacional de la inversión, a continuación se analizan algunas de las principales formas administrativas que al ser aplicadas en un determinado país, podrían dar lugar a violación del derecho internacional de la inversión.

La primera forma administrativa que nos ocupa es el denominado ius variandi ${ }^{32}$, que es la prerrogativa que tiene el Estado de modificar unilateralmente al contrato administrativo. El ius variandi se puede producir de manera directa hacia el contrato administrativo, como por ejemplo cuando se modifica una regulación de telecomunicaciones, que afecta directamente el contra-

31. En el derecho internacional las formas de remediación del daño son restitución, compensación y satisfacción. La primera se implica reponer las cosas al estado anterior al del daño, la segunda comprende un pago en dinero suficiente cono compensar el daño causado, y la tercera constiuye una declaración de buena voluntad muy poco común en el derecho moderno.

32. Jaime Rodríguez-Arana, Derecho Administrativo Español, Ed. Porria, México, 2005, pp. 199 y 200. 
to administrativo de una concesión de telecomunicaciones. Por otro lado, el ius variandi puede producirse de manera indirecta; por ejemplo, cuando se expide una regulación municipal que regula el uso del suelo, y que afecta indirectamente la instalación de antenas para teléfonos móviles.

La aplicación del ius variandi produce lo que la doctrina ha denominado el factum principis o hecho del príncipe ${ }^{33}$, entendido como la modificación unilateral del contrato administrativo por parte del Estado o sus órganos, alternado así el equilibrio o la fórmula económico-financiera del contrato administrativo. El ejercicio del ius variandi lleva implícita la obligación del Estado de reestablecer el equilibrio económico del contrato ${ }^{34}$ o compensar al contratista. Sin embargo, con el ánimo de evitar las compensaciones a los contratistas, motivar ciertas formas de contratación administrativa y fomentar la seguridad jurídica en los contratos administrativos, tanto la doctrina administrativista como el ordenamiento jurídico de varios países, han limitado el ejercicio del ius variandi, ${ }^{35}$ promoviendo la intangibilidad ${ }^{36}$ de los contratos administrativos.

El ius variandi no viola el derecho internacional de la inversión per se, aunque puede hacerlo, si la medida adoptada por el

33. Rodriguez-Arana hace una distinción entre el ius variandi y el factum principis. Define al primero como aquel que se produce cuardo la Administración "modifica el contrato" y "debe compensar al contratista por todas las consectiencias económicas de la modificación. Esta compensación engloba tanto el daño emergente como el lucro cesante... Ctando las modificaciones afectan el régimen financiero del contrato -de servicios públicos-, la Administración deberá compensar al contratista de mantera que se mantenga el equilibrio de los supuestos económicos que fueron considerados como básicos en la adjudicación del contrato." Id. Así también el Autor define al hecho del príncipe como la "adopción por la Administración de cientas medidas de carácter general e imprevisible, ajenas al contrato o 'externas' (es deci), no relativas a la relación Administración-contratista) y por ende no directamente relacionadas con el objeto del contrato, pero qute provocan indirectamente un daño especial al contratista)... En estos casos, las exigencias de equilibrio económico del contrato generan un derecho a indemnizacion a favor del contratista periudicado." Id.

34. El restablecimiento del equilibrio del contrato puede alcanzase mediante la extenșión del plazo del contrato, el incremento de las tarifas o ingresos del contratista o la reducción de cargas impositivas.

35. Por ejemplo, la Constitución del Ecuador dispone que los contratos administrativos tendrán una garantía de estabilidad juridica en los articulos 249 y 271.

36. Rodriguez-Arana, pp. 196-197. La legislación española hace referencia a lo que se ha denominado la regla de la inalterabilidad del contrato ("pacta sint servanda, contractus lex inter partes"), es decir que el contrato no puede ser altemado unilateralmente por la sola voluntad de una parte bajo el principio de buena fe. 
Estado o alguno de sus órganos ${ }^{37}$ viola los preceptos del derecho internacional de la inversión. Por ejemplo, se activará el derecho internacional si el factum principis es discriminatorio, o si éste constituye un acto de expropiación o viola el trato justo y equitativo. La jurisprudencia internacional tiene varios casos en los que un inversionista y contratista a la vez ha alegado ius variandi, identificándolo o no como tal, y encajándolo dentro de los estándares del derecho internacional de la inversion..$^{38}$ Bajo las reglas de la carga de la prueba en el derecho internacional, competerá al inversionista y contratista que alegue la violación, demostrar que tal acto de ius variandi y factum principis constituye un acto discriminatorio, expropiatorio o violatorio del trato justo y equitativo.

Otra institución propia del derecho administrativo, y en particular del contrato administrativo, es la terminación unilateral del contrato administrativo. ${ }^{39}$ Como hemos indicado, el contrato administrativo es peculiar por varias razones; entre ellas, por la posibilidad que tiene de contenex cláusulas exhorbitantes, es decir, de aquellas en las que el Estado ejerce una posición de desigualdad y superioridad frente al contratista, y lo supedita en aras de valores superiores como los fines y mandatos del Estado, a situaciones que pueden ser no equitativas y que se encuentran previstas en las normas de orden público que rigen a los contratos administrativos.

37. Es menester tener presente que el ius variandi considera la personalidad de la Administración, y el hecho de que el Estado/Administración Pública es uno solo. Por lo tanto, la afectación al contrato puede provenir de cualquier órgano del Estado, es decir, no solo del órgano que funge de contraparte en el contrato administrativo. Ergo, tal personalidad única produce una responsabilidad del sujeto Estado en su integridad.

38. Muchos de los casos de arbitraje producto del Convenio entre Irán y los Estados Unidos de América para la solución de las controversias producidas luego de la revolución islámica contemplaron contratos suscritos con el Estado iraní y teminados abruptamente. Estos casos constituyen un icono importante en el análisis de esta materia.

39. La doctrina distingue varias formas de terminación unilateral, como por ejemplo la caducidad, la terminación anticipada, sea por razones de oportunidad o necesidad, o como formas de sanción al contratista por un determinado incumplimiento del contrato o por acumulación de incumplimientos menores. Véase Roberto Dromi, Derecho Administrativo. Ed. Ciudad Argentina, Bs. As. 
La terminación de un contrato administrativo puede configurar también una violación del derecho internacional de la inversión, cuando de manera particular tal medida constituye un acto discriminatorio, expropiatorio o violatorio del trato justo y equitativo. Por ejemplo, si la terminación del contrato está dirigida solo en contra de un contratista y no obedece a una actuación uniforme respecto de otros contratistas nacionales o extranjeros en similares circunstancias, entonces podría haber lugar a una actuación discriminatoria. $\mathrm{Si}$, por ejemplo, la terminación de un contrato administrativo conlleva la apropiación de inversiones del inversionista y contratista sin la debida compensación, entonces podría haber lugar a una actuación expropiatoria de facto que viola las normas del derecho internacional de la inversión.

Otra institución puramente administrativa que puede dar lugar a la aplicación de normas del derecho internacional de la inversión es la expropiación administrativa, entendida como el proceso reglado, con finalidad pública, de transferencia forzosa de propiedad de un ciudadano a favor del Estado.

La expropiación administrativa estaría dentro de la denominada expropiación de jure en el derecho internacional. Sin embargo, la expropiación administrativa, aunque sea un proceso reglado, puede dar Iugar a la aplicación del derecho internacional cuando, por ejemplo, no se pague la correspondiente compensación, o cuando la compensación no sea adecuada ${ }^{40}$, sea insuficiente, se pague con retraso, no haya sido valorada bajo los términos de un tratado de inversión o se pague en una moneda que no sea libremente convertible.

40. Véase Compañía de Desartollo de Santa Elena v. República de Costa Rica, ICSID caso No. ARB/96/1, Laudo de 17 de Febrero de 2000. 


\section{Conclusiones}

En el mundo actual, orientado a una integración en varias áreas, es innegable que existe una integración jurídica, la cual el derecho administrativo y el derecho internacional no pueden desconocer. El derecho administrativo de los países de origen continental puede verse influido e incluso supeditado al derecho internacional de la inversión.

En cuanto al contrato administrativo, éste se rige primordialmente por el derecho administrativo, mas puede verse sujeto a normas sustantivas y adjetivas de derecho internacional de la inversión que rijan su desarrollo.

Para que un contrato administrativo pueda verse sujeto al derecho internacional de la inversión, será necesario que exista derecho internacional aplicable al Estado que es parte del contrato administrativo, generalmente en la forma de un tratado de inversión o de comercio. Además, será necesario que exista una inversión y un inversionista en los términos de cada uno de los tratados.

Finalmente, varias de las formas administrativas de actuación del Estado o de la Administración Pública que lo personifica en su fuero doméstico, pueden activar al derecho internacional de la inversión (derecho sustantivo), permitiendo su aplicación y sustrayendo una eventual controversia del foro propio del contrato (derecho adjetivo). ${ }^{41}$ Cuando esto sucede, el derecho administrativo y las actuaciones locales dejan de ser el derecho sustantivo rector de la controversia, y se convierten en hechos que deben probarse en la controversia internacional. Por lo

41. Es necesario aclarar que se aplica el derecho internacional como derecho sustantivo de una controversia cuando se activa una norma de derecho internacional que sería, en términos de Gordillo, revestida de "supremacia" juridica por sobre el orden nacional, "provista de fuerza coactiva, de imperatividad". Gordillo, p. VI-24. Sin embargo, el derecho intemacional puede quedarse en el plano adjetivo, cuando solo se aplica la norma internacional adjetiva, por ejemplo, cuando solo acude al arbitraje internacional (i.e. ICSID), pero la ley sustantiva de la controversia es la ley doméstica, pues no se ha invocado, o no existe causa, o no existe tratado o no se han presentado los elementos necesarios para aplicar el derecho internacional. 
tanto, el contrato administrativo, si bien puede continuar siendo el eje de la disputa, los derechos sustantivo y adjetivo de la misma pueden ser substituidos. Es decir, se reemplazaría el derecho administrativo (sustantivo) que rige el contrato por el derecho internacional, convirtiéndose aquel -el administrativoen un elemento más de prueba, pero el derecho sustantivo o la ley aplicable a la controversia pasa a ser el internacional. También, las cortes domésticas pueden ser reemplazadas (adjetivo), sean jurisdiccionales o convencionales, por tribunales internacionales, sin que exista necesariamente un compromiso arbitral en el contrato administrativo. ${ }^{42}$

42. Los convenios internacionales de protección de inversiones tienen una forma de consentimiento arbitral denominado "arbitration without privity", por el cual, el consentimiento del Estado a acudir al arbitraje de inversión bajo el derecho internacional consta en el tratado mismo, y se requerirá el compromiso del inversionista y contratista una vez surgida la controversia, momento en el cual se configura el convenio o compromiso arbitral. 
Cuadro No. 1

A continuación un cuadro que resume las conclusiones de este trabajo. El cuadro pretende demostrar como algunas instituciones del derecho internacional se pueden aplicar cuando el derecho administrativo produce efectos domésticos bajo diversas formas.

\begin{tabular}{|l|l|l|l|}
\hline & $\begin{array}{l}\text { Discriminación en el } \\
\text { derecho Internacional } \\
\text { (trato nacional y cláu- } \\
\text { sula de la nación más } \\
\text { favorecida) }\end{array}$ & $\begin{array}{l}\text { Expropiación de } \\
\text { jure o de facto en } \\
\text { el derecho inter- } \\
\text { nacional }\end{array}$ & $\begin{array}{l}\text { Trato justo y } \\
\text { equitativo en el } \\
\text { derecho interna- } \\
\text { cional }\end{array}$ \\
\hline $\begin{array}{l}\text { Ius Variandi y } \\
\text { hecho del príncipe }\end{array}$ & Puede producirse & $\begin{array}{l}\text { Puede producirse. } \\
\text { Es más probable } \\
\text { que la expropia- } \\
\text { ción sea de facto al } \\
\text { darse el hecho del } \\
\text { príncipe }\end{array}$ & Puede producirse \\
\hline $\begin{array}{l}\text { Terminación uni- } \\
\text { lateral del contra- } \\
\text { to administrativo }\end{array}$ & Puede producirse & $\begin{array}{l}\text { Si. } \\
\text { La terminación } \\
\text { del contrato } \\
\text { puede ser una } \\
\text { expropiación de } \\
\text { jureo de facto bajo } \\
\text { el derecho inter- } \\
\text { nacional. Si se } \\
\text { siguió un proceso } \\
\text { reglado, puede } \\
\text { estar bajo la } \\
\text { expropiación de } \\
\text { jure }\end{array}$ & \\
\hline $\begin{array}{l}\text { Exp ropi iaci ón } \\
\text { Administrativa } \\
\text { (proceso reglado } \\
\text { y doméstico) }\end{array}$ & Puede producirse & $\begin{array}{l}\text { Probablemente se } \\
\text { tratara de una } \\
\text { expropiación de } \\
\text { juté }\end{array}$ \\
\hline
\end{tabular}


3. Sección de

Ensayos y

Doctrina 
, 